\section{Aizoaceae (Magnoliopsida: Caryophyllales) - a new family record to the flora of Andaman Islands, India}

\section{Rasingam}

Botanical Survey of India, Deccan Regional Centre, Plot No. 366/1, in Zoological Survey of India Campus, Attapur, Hyderabad, Andhra Pradesh 500048, India

Email: rasingam@gmail.com

The Family Aizoaceae (Fig-marigold family or Ice plant family) comprises 127 genera and about 1860 species (Mabberley 2008) distributed mostly in the arid and semi-arid regions of Africa and a few of them from Asia, Australia and the central Pacific regions. Majority of the species (96\%) are endemic to southern Africa (Chesselet et al. 2000). In India the family is represented by three genera, namely, Sesuvium, Trianthema and Zaleya with seven species distributed in the coastal and lowland areas of peninsular India and the Gangetic plains (Karthikeyan et al. 2009).

The genus Sesuvium L. comprises of about 22 species distributed in the warmer parts of the world, mostly confined to the tropics and sub-tropics worldwide (Mabberley 2008). In mainland India, the genus is represented by two species namely $S$. portulacastrum (L.) L. distributed in the coastal

Date of publication (online): 26 June 2012

Date of publication (print): 26 June 2012

ISSN 0974-7907 (online) | 0974-7893 (print)

Editor: N.P. Balakrishnan

Manuscript details:

Ms \# 03075

Received 20 January 2012

Final received 19 March 2012

Finally accepted 21 May 2012

Citation: Rasingam, L. (2012). Aizoaceae (Magnoliopsida: Caryophyllales) - a new family record to the flora of Andaman Islands. Journal of Threatened Taxa 4(6): 2653-2655

Copyright: (c) L. Rasingam 2012. Creative Commons Attribution 3.0 Unported License. JoTT allows unrestricted use of this article in any medium for non-profit purposes, reproduction and distribution by providing adequate credit to the authors and the source of publication.

Acknowledgements: I am grateful to the Director, Botanical Survey of India, Kolkata for facilities, and the Officer in Charge, Botanical Survey of India, Deccan Regional Centre, Hyderabad for encouragements and Dr. K. Karthigeyan, Central National Herbarium, Howrah, for suggestions. I also thank the officials of ANFPDCL for field support

OPEN ACCESS | FREE DOWNLOAD areas and $S$. sesuvioides (Fenzl) Verdc., distributed in Gujarat and the Upper Gangetic Plains

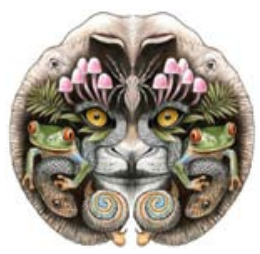
(Karthikeyan et al. 2009). During the course of studies on the floristic diversity of Little Andaman Island, the author collected a succulent prostrate herb with pink flowers from the sandy coasts of South Bay area. On critical examination and study of the specimen, it was identified as Sesuvium portulacastrum (L.) L. Survey of literature revealed that its occurrence has not been reported from these islands so far (Rao 1986; Lakshminarasimhan \& Rao 1996; Mathew 1998; Pandey \& Diwakar 2008). It is now reported here as a new addition to the flora of Andaman and Nicobar Islands. The collection of this species from Little Andaman Island also forms a new addition of the family Aizoaceae to the flora of Andaman and Nicobar Islands. A brief description, photographs and uses are given for easy identification and further utilization of this economically important plant.

\section{Sesuvium portulacastrum (L.) L.}

Syst. Nat., ed. 10. 2: 1058. 1759; Roxb., Fl. Ind. [ed. Carey] 2: 509. 1832; C. B. Clarke in Hook.f., Fl. Brit. India 2: 659. 1879; Ridl., Fl. Malay. Penins. 1: 866. 1922; Backer in Steenis, Fl. Males., Ser. 1, Spermat. 4: 272. 1951; Karthik. et al., Fl. Pl. India-Dicot. 66. 2009. Portulaca portulacastrum L., Sp. Pl. 446. 1753. (Images $1 \& 2$ ).

Specimen examined: 27.xi.2005, South Bay, Little Andaman Island, Andaman and Nicobar Islands, India, coll. L. Rasingam \#25973 (PBL - Herbarium of the Botanical Survey of India, Andaman and Nicobar Regional Centre, Port Blair).

Small prostrate herb; stems reddish, succulent, rooting at nodes, densely caespitose, glabrous. Leaves simple, opposite, fleshy, lanceolate, linear-lanceolate, often oblong, 20-50 x 5-10 mm, attenuate at base, entire along margins, obtuse at apex, flat above, convex beneath. Petioles very short, ca $7 \mathrm{~mm}$ long, dilated at the base into a scarious, semi-amplexicaul sheath. Flowers solitary in the leaf axils; pedicels up to $1 \mathrm{~cm}$ long, thickened upwards, glabrous. Perianth segments broadly lanceolate or oblong-ovate, ca $8 \times 4 \mathrm{~mm}$, central thicker parts green, thin, imbricate, margins pink, 

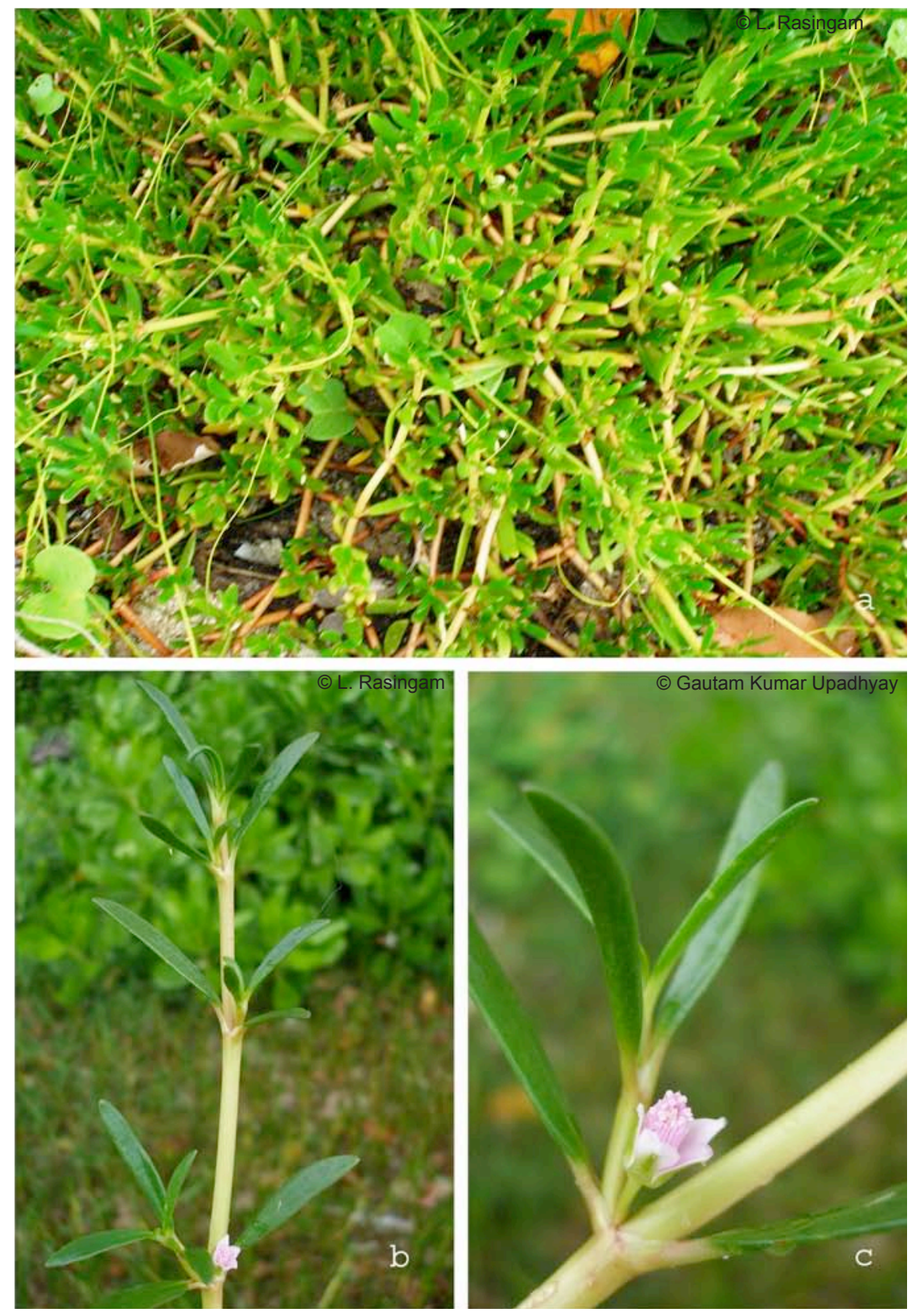

Image 1. Sesuvium portulacastrum (L.) L. (Aizoaceae)

a - Habit; b - Flowering twig;

c - Flower

inner surface pink, apex with fleshy apiculus. Stamens many, included; filaments free, coherent at base, pink; anthers dark coloured. Ovary 3-4-locular, glabrous. Styles as many as locules, white. Capsule included by the perianth, oblong, ca $10 \mathrm{~mm}$ long; seeds many, orbicular, long-funicled, shining black.

Flowering \& fruiting: Throughout the year.

Distribution: Cosmopolitan in the tropics, seashores of eastern and western coasts in India. Presently recorded from Andaman Islands.

Habitat \& ecology: Rare, in the sandy beaches and along the tidal creeks between 0 to $5 \mathrm{~m}$ above sea level in association with Wedelia biflora, Ipomoea pescaprae, Launaea sarmentosa, Ischaemum muticum, I. rugosum and Crinum asiaticum.

Uses: The whole plant is sold in the markets of Asian countries as a green vegetable. It is also a good fodder for cattle and cultivated as a sand-binder in eroded sea shores.

\section{REFERENCES}

Chesselet, P., G.F. Smith, P.M. Burgoyne, C. Klak, S.A. 


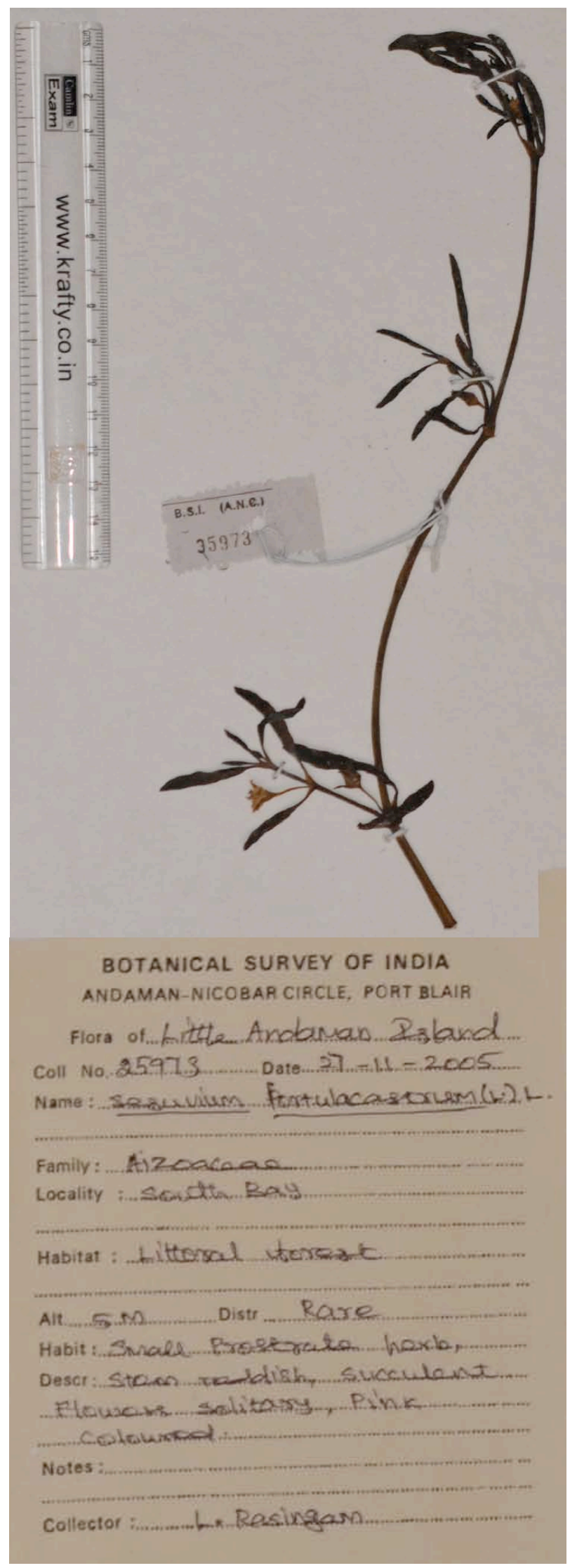

Image 2. Herbarium image of Sesuvium portulacastrum (L.) L. (Aizoaceae)
Hammer, H.E.K. Hartmann, H. Kurzweil, E.J. van Jaarsveld, B.E. van Wyk \& O.A. Leistner (2000). Mesembryanthemaceae. In: Leistner, O.A. (ed.). Seed Plants of Southern Africa. Strelitzia 10: 360-410.

Karthikeyan, S., M. Sanjappa \& S. Moorthy (2009). Flowering Plants of India. Dicotyledons. Vol. 1 (Acanthaceae - Avicenniaceae). Botanical Survey of India, Kolkata, 365pp.

Lakshminarasimhan, P. \& P.S.N. Rao (1996). Supplementary list of angiosperms recorded (1983-1993) from Andaman and Nicobar Islands. Journal of Economic and Taxonomic Botany 20: 175-185.

Mabberley, D.J. (2008). Mabberley's Plant-Book; A Portable Dictionary of Plants, Their Classification and Uses. $3^{\text {rd }}$ revised edition, Cambridge University Press, Cambridge, U.K., XVIII+1021pp.

Mathew, S.P. (1998). A supplementary report on the flora and vegetation of Bay Islands, India. Journal of Economic and Taxonomic Botany 22: 249-272.

Pandey, R.P. \& P.G. Diwakar (2008). An integrated checklist of plants in Andaman \& Nicobar Islands, India. Journal of Economic and Taxonomic Botany 32: 403-500.

Rao, M.K.V. (1986). A preliminary report on the angiosperms of Andaman and Nicobar Islands. Journal of Economic and Taxonomic Botany 8: 107-184. 